\title{
Nature Of Information Provided And Quality Of Sustainability Reports Assurance Statements Of Fortune Global 500 Companies
}

Tarmizi Achmad, Universitas Diponegoro, Indonesia Faisal Faisal, Universitas Diponegoro, Indonesia

Muhammad Bahrul Ulum, Universitas Diponegoro, Indonesia

\begin{abstract}
The objective of this study is to investigate how the quality of assurance statement varies among the different assurance providers (accounting versus non-accounting firms). The sample consists of one hundred thirty-five of Fortune Global 500 companies for the year 2014. Independent sample t-test is used to determine how the quality of assurance statement differs among various assurance providers.

The result shows that accounting firms still dominate the sustainability report assurance market (75.56 per cent), while non-accounting firms is 24.44 per cent. However, in terms of quality score of assurance statement, nonaccounting assurance providers (consultant) value higher than accounting firms for all aspects of report content (reporting format, assurance procedures and recommendations and opinion).

The implication of this finding suggests that the company not only to consider the reputation of the assurance provider, but the more important thing is competence and expertise in the field of sustainability reporting. Despite the growing interest research in assurance, this study is one of the few studies that measure assurance quality by content analysis.
\end{abstract}

Keywords: Assurance; Sustainability Report; Fortune Global 500; Content Analysis

\section{INTRODUCTION}

(D) ustainability reporting (SR) practice becomes prevailing eventually nowadays. The KPMG's annual survey in 2013 reports that nearly three-quarters of the 4.100 biggest companies from 41 countries around the world adopt the practice of SR (KPMG, 2013). The significant increase in the publication of the report has been accompanied by mounting up interest in the accuracy of these reports (Simnett, Vanstraelen \& Chua 2009; O'Dwyer, 2011; GRI, 2013) and as a consequence, there is a need for external assurance or verification (Pflugrath, Roebuck \& Simnett,2011). To date, researchers in the field of SR have given a modest attention on the potential benefits of SR assurance (Cho, Michelon, Patten \& Roberts,2014). Pressures from stakeholders have actively encouraged companies to consider seriously the importance of assurance sustainability report to enhance the quality of social and environmental information and provide the extra accuracy sustainability performance data to support decision making (Park \& Brorson, 2005; Moroney, Windsor \& Aw 2012; Zorio, Garcia-Benau \& Sierra 2013; Wong \& Millington, 2014; Cohen \& Simnett, 2015). Such the valuable of corporate social and environmental performance may also help certainly stakeholders to draw well on other private disclosures for making effectively socially responsible for investment (Wong \& Millington, 2014).

Previous studies argue that assurance statements in sustainability reports can enhance the clarity and reliability of these statements (Deegan, Cooper \& Shelly 2006; Hodge, Subramaniam \& Stewart 2009), increase stakeholder trust 
in the level of organizational commitment to sustainability agendas (Simnett et al. 2009), maintain stakeholders trust as well as reducing risk (Jones \& Solomon, 2010; Branco, Delgado, Gomes \& Eugenio 2014), and to demonstrate company legitimacy as well as to comply with regulations (Ackers \& Eccles, 2015). Despite this growing interest, there is quite limited research into the assurance quality (Cohen \& Simnett, 2015), specifically by content analysis except for (Perego, 2009; Perego \& Kolk, 2012; Zorio et al. 2013). Most previous works, for example, (Simnett et al. 2009; Mock, Rao \& Srivastava, 2013; Cho et al. 2014; Herda, Taylor \& Glyn 2014; Wong \& Millington, 2014; Kend, 2015) tend to focus on the adoption of an assurance statement sustainability report, rather than measuring the contents quality of the statement itself. Sustainability reporting assurance research should examine the quality of sustainability assurance statements rather than merely their adoption (Kolk \& Perego, 2010 p.195). The value of an assurance statement is exhibited by a number of attributes, such as clarity of statement, independence, responsibility, and competence of assurance provider. Consequently, by analyzing the content, scope, and quality of sustainability assurance statements, researchers could provide insight on aspects of the underlying and the complexity of the real assurance practice (Deegan et al. 2006; Junior, Best \& Cotter 2014). The gaps will be addressed in the current study.

Thus, the mainly aim of this study is to extend the sustainability reporting assurance research by assessing the quality of assurance statement of Fortune Global 500 companies for the period of 2014. Specifically, it investigates to what extent do assurance statements address the content of the report (reporting format, assurance procedure and recommendation/opinion). As there are many stakeholders concerned in the quality of assurance statement (Green $\&$ Taylor, 2013), measuring the quality of sustainability report assurance statement may add a deeper understanding to the assessment of assurance statement criteria (relevance, completeness, reliability, neutrality, and understandability). Without a high balanced of transparency the assurance process for sustainability reports could be officially contemplated just a procedural and non-important activity (Junior, et al, 2014). The second objective is to examine the effect of assurance providers' type on the quality of assurance statement. Past studies propose that there are substantial discrepancies between accountants and consultants in terms of level or breadth of the assurance provided (O’Dwyer\& Owen, 2005; Mock et al. 2007; Perego, 2009; Perego \& Kolk, 2012).

This study is related to the work of Perego and Kolk (2012), they use a sample from Fortune's Global 500 list as published on 3 August 1998 which is old. Moreover, their study may contain a potential bias as regards their sample, as they included non-English sustainability reports. Our study uses 135 English sustainability reports of Fortune Global 500 companies listed in 2014, which adequately represent the present data and practice of sustainability assurance statements. By using the most recent data, the results of this study will contribute to further understanding concerning how the current status of an assurance statement content. We focus on variation of quality assurance statements of assurance providers. In addition, Perego and Kolk (2012) measure the quality assurance statements by calculating the total score of the content of the report. Besides measuring quality, recent study also looks at the difference of the nature of information-provided in an assurance statement report between providers. The quality of assurance statement is determined by content analysis. Our study employs an index used by Perego and Kolk (2012) based on the framework provided by O'Dwyer and Owen (2005). Consistent with our prediction, we find the mean of assurance quality is 18.97 , higher compared to Perego and Kolk (2012) which is 13.71 . Moreover, the finding of this study suggests that non-accounting firms provide a higher quality of sustainability report assurance than accounting firms.

\section{LITERATURE REVIEW}

\subsection{Sustainability Reporting and Assurance Practice}

In the context of sustainability reporting, the practice to employ independent third party to assure sustainability report is increasing year by year. Perego and Kolk (2012) find that the proportion of assured sustainability report is rising from 21,4 per cent in 1999 to 55,8 per cent in 2008. Assurance on sustainability report can be conducted by various professions. CorporateRegister (2013) reports that major accounting firms dominated the market. KPMG (2013) finds that 67 per cent of 1.099 surveyed companies choose to have the reports assured by major accounting firms. In line with Perego and Kolk (2012), CorporateRegister (2013) documents that the market share of accountants on sustainability report assurance increase from 37 per cent in 2007 to 51 per cent in 2011 . The other providers such certification bodies, specialist consultancies, and others hold 27 per cent, 15 per cent, and 7 per cent respectively. 
A significant increase in the number of sustainability assurance reports indicate that company in the past five years is considered necessary to improve the credibility of CSR information to stakeholders (Park \& Brorson, 2005). An assurance statement also can be seen as a positive signal on the credibility of CSR performance own (Brown-Liburd \& Zamora, 2015). A firm may consider whether or not to seek an independent external assurance or auditors to verify and enhance the credibility of sustainability report (O'Dwyer et al, 2011 p.32). The overwhelming desire to improve the credibility of the report could have been caused by the presence of certain motives of the company, for example, to legitimize their CSR activities, meet stakeholders demand or increase the company's value. For instance, the adoption of such voluntary assurance statements may lift the reputation of companies and strengthen and legitimize their social responsibility activities (Faisal, Tower \& Rusmin, 2012 p.30) or as an advertisement for the company and not as a signal for future corporate value (Ballou, Heitger \& Landes, 2006).

\subsection{Assurance Quality and Assurance Provider}

Deegan, et al (2006) find that there are much considerable variability and ambiguity inherent within the contents of third-party statements. The variability in the content of the assurance statements may be affected by many factors, one of which is the assurance provider, which in the end may certainly affect the quality of the assurors report. Mock, et al (2007) imply that level of assurance statements closely related to the assurance provider. While, De Beelde and Tuybens (2015) argue that selection of the appropriate assurance provider will substantially reduce the high variation in the format and at the same time will maintain the quality of the assurance statement.

There are few early studies have been examining the effect of different assurance providers on the quality of assurance statements. For example, Perego (2009) finds that Big Four accounting firms to provide higher quality of assurance in comparison with other assurance providers in terms of assurance reporting format and procedures used when conducting verification, but provide a lower quality in terms of recommendations and opinion. Later study, Perego and Kolk (2012) details that assurance statements provided by accounting firms have a mean quality score of 13,75 . However, the quality is just slightly higher with the mean quality score of assurance statements provided by specialists who is 13,50 , while the quality scores of assurance statements provided by certification bodies and other assurance providers are 10,80 and 5,89 respectively.

The trend to hire the auditor (Big Four) documented by CorporateRegister (2013), Gomes, Eugenio \& Branco (2015), which indicate that accounting firms, especially Big Four auditor provides a more comprehensive approach to assure sustainability report. Francis and $\mathrm{Yu}$ (2009) argue the reason Big Four auditors have a higher audit quality. It is because they have more collective experience in administering the audit of public companies. In addition, accountants have good reputation that they are well-known in society. Accordingly, accountants, especially the Big Four, are less likely to behave myopically or opportunistically and they have well developed global standards and strict ethics, expert, independent, and control requirements (Simnett, et al, 2009; (Pflugrath, et al, 2011). As a result, accountants proposed to serve as an effective control mechanism (Watts and Zimmerman, 1983). Knechel, Wallage, Eilifsen \& Praag (2006) suggest that professional reputation and integrity are highly important attributes in selecting the auditor to provide assurance.

However, several other studies claim that consultants or specialist provide better quality than the accounting firms in terms of assurance statement services. O'Dwyer and Owen (2005) explain that consultants tend to give a more strategic approach to the assurance exercise, which might be considered as added value for stakeholders. In terms of independence and expertise, an environmental specialist is more likely to be selected by stakeholders as an assuror than the financial auditors (Wong and Millington, 2014). Nevertheless, De Beelde and Tuybens (2015) conclude that the relationship between the selection of the provider with the quality of assurance statements still converging. Pflugrath, et al (2011) find there is no significant difference between financial analysts in Australia and UK in terms of perceived credibility of CSR information assured by members of the accounting profession and independent experts. Therefore, the proposed hypothesis regarding the effect of assurance providers on the quality of assurance statements is:

H1: The quality of sustainability report assurance statements differs across the assurance provider 


\section{RESEARCH METHODS}

\subsection{Sample Selection}

Given that information in sustainability report that is assured may contain all categories (e.g: using GRI 4 categorization: economic, environmental, and social) or single category (such as environmental information only), this study focuses on the assurance statement for information in the comprehensive sustainability reporting (contain not only single aspect). This approach is expected to avoid bias in comparing the assurance statements since the information assured is nearly the same. This study uses sustainability report data for the year 2013, by exploring the companies' website and the third-party database such as CorporateRegister. Content analysis of 135 sustainability report assurance statements for the year 2013 from Fortune Global 500 companies are employed. Fortune Global 500 have been used by some past studies see, for example, (Kolk \& Perego, 2010; Perego \& Kolk, 2012; (Junior, et al, 2014). These large multinational companies (MNCs) have been more much more active in sustainability reporting practice, which means that their 'behavior' can help to explain sustainability reporting practice among MNCs. Table 1 presents the sample selection.

Table 1. Sample selection

\begin{tabular}{l|c}
\hline & Number of Companies \\
\hline Fortune Global 500 Companies: 2014 list & 500 \\
\hline Companies have English sustainability assurance statement & 158 \\
\hline The assurance statement cannot be found & $(12)$ \\
\hline Sustainability reports contain merely opinion and rating & $(11)$ \\
\hline Final Sample & $\mathbf{1 3 5}$ \\
\hline
\end{tabular}

\subsection{Variable Measurement}

The quality of assurance statement is determined by content analysis. This research employs an index applied by Perego and Kolk (2012) based on the framework provided by O'Dwyer and Owen (2005). The index consists of 19 criteria. The criteria evaluate the quality of assurance statements on three aspects: reporting format, assurance procedures, and recommendations and opinion. The possible score based on the criteria is ranged from 0 to 27 (see Appendix A and Table 3 for scoring details). Assurance statements are perceived having higher quality if they have a higher score. To ensure content analysis has been conducted properly, and the data produced reliable, two experienced coders are employed. Coding discrepancies between these coders will be re-analyzed and reconciled (Milne \& Adler, 1999). Assurance services can be conducted by various professions. In this study, assurance providers are determined by a dummy variable. If the assuror is an accounting firm, then the variable is given value of 1 . While the assuror is other than accounting profession, a 0 is assigned.

\section{FINDINGS AND DISCUSSION}

\subsection{Descriptive Statistics and Independent Sample T-Test}

Based on the descriptive statistics (Table 2), accounting firms provide 102 assurance statements (75.56 per cent) from all the samples, while non-accounting firms provide 33 assurance statements (24.44 per cent). This result shows that accounting firms dominate the assurance market, which is consistent with the findings of KPMG (2013), CorporateRegister (2013), Ackers and Eccles (2015) and (De Beelde \& Tuybens, 2015). PricewaterhouseCoopers $(\mathrm{PwC})$ is the most frequent assurance provider with 32 assurance statements $(23.70$ per cent). The other three Big Four accounting firms: Ernst \& Young, KPMG, and Deloitte provide 24 assurance statements (17.78 per cent), 28 assurance statements (20.74 per cent), and 12 assurance statements ( 8.89 per cent) respectively. The result indicates that many companies perceived accounting firms as the most credible assurance providers. Big Four auditors' dominance as a provider of assurance can be attributed to the reciprocal relationship with a provider of assurance and also financial audit services. By providing both these services, Big Four auditors can improve efficiency in conducting the audit and at the same time maintaining good relations between auditor and company (Ackers and Eccles, 2015). Another explanation of this finding is that the higher cost incurred to choose accounting firms as an 
assurance provider seems not a problem for these multinational companies (Simnett, et al, 2009). The rest six assurance statements are from other non-Big Four accounting firms or group of accounting firms. Non-accounting firms provide 33 assurance statements (24.44 per cent). Bureau Veritas and DNV are the most frequent nonaccounting firms assurance provider. Each of them yields largely seven assurance statements (5.19 per cent). LRQA assured four reports (2.96 per cent). ERM CVS and KPC give three assurance statements $(2.22$ per cent). The other non-accounting firms provide each one statement. The result suggests that nearly a quarter of the companies use non-accounting firms to provide assurance on their sustainability reports.

Table 2. Descriptive statistic for assurance providers

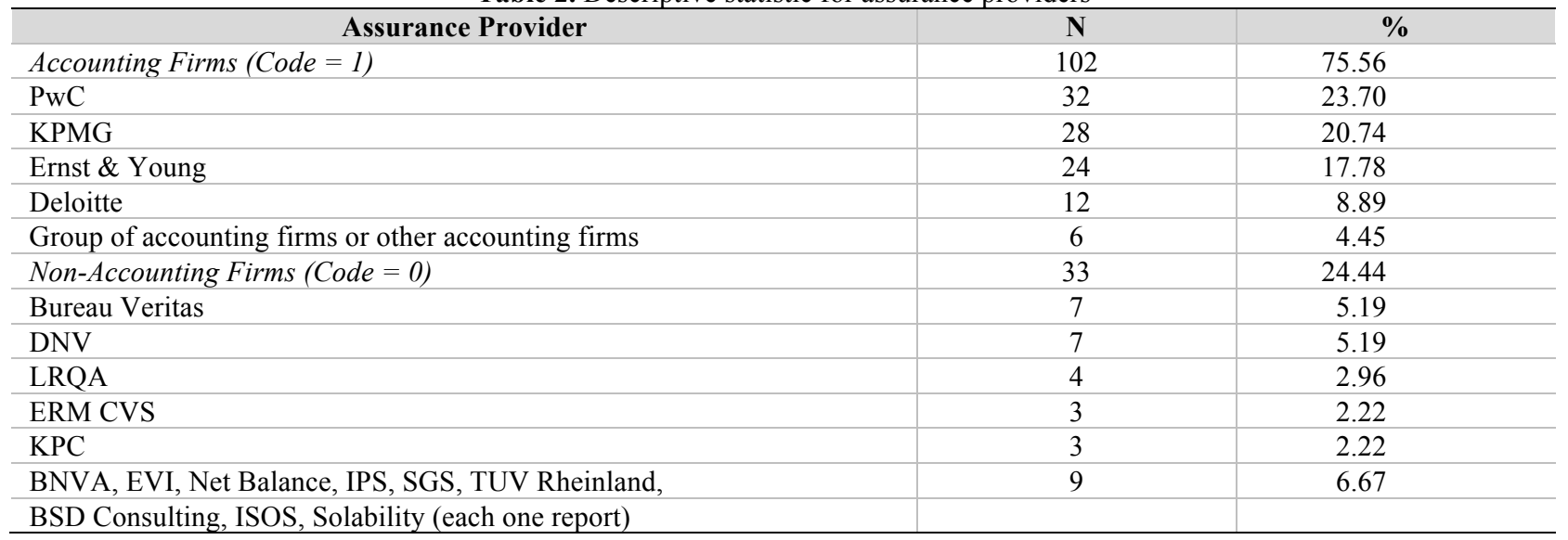

Table 3 presents the detailed overview of the nature of the information provided for the assurance statement for all samples (Panel A), and based on the assurance provider (Panel B and C). More than 80 per cent assurance statements use a similar reporting format such as title, address, name and location of assuror, report date, responsibilities of reporters and assurors, and independence of assuror. However, less than 30 per cent of statements contain impartiality of assuror towards stakeholders' information, while non-accounting firms are more likely (more than 75 per cent) disclose the information. In terms of assurance procedures, the accounting firms disclosed 92.8 per cent, whereas non-accounting firms assuror to provide higher than those (94.5 per cent). At the same time, nonaccounting firms report a lower information about assurance standard used ( 84.9 per cent) compared to accounting firms. O'Dwyer and Owen (2005) suggest that accountants tend to use the standard to reflect emerging best practice and also to comply with the principles of international standards, while non-accountant assurors are more likely to employ a particular standard in assurance engagement (p.217). The frequency of the information about the materiality, completeness, and responsiveness varies widely between accounting firms and non-accounting firms. Approximately 66.7 per cent of the non-accounting firms disclosed materiality, whereas only 33.3 per cent of 102 companies assured by accounting firms, provide materiality information. Furthermore, most of the assurance statements of the non-accounting firms report more information regarding completeness (66.7 per cent) and responsiveness to stakeholders (57.6 per cent) than accounting firms. O'Dwyer and Owen (2005) report that consultant assurors are more likely to focus much more on the issues of completeness, fairness, and overall balance of within their opinion statements (p.225). 
Table 3. Overview of the nature of the information provided on the assurance provider

\begin{tabular}{|c|c|c|c|c|c|c|c|}
\hline \multirow[t]{3}{*}{ No } & \multirow[b]{2}{*}{ (minimum - maximum score) } & \multirow{2}{*}{\multicolumn{2}{|c|}{$\begin{array}{c}\text { Panel A } \\
\text { All sample } \\
(\mathrm{N}=135)\end{array}$}} & \multirow{2}{*}{\multicolumn{2}{|c|}{$\begin{array}{c}\text { Panel B } \\
\text { Accounting } \\
\text { firms } \\
(\mathbf{n}=\mathbf{1 0 2})\end{array}$}} & \multirow{2}{*}{\multicolumn{2}{|c|}{$\begin{array}{c}\text { Panel C } \\
\text { Non-accounting } \\
(\mathbf{n}=\mathbf{3 3})\end{array}$}} \\
\hline & & & & & & & \\
\hline & A. Reporting format & $n$ & $\%$ & $n$ & $\%$ & $n$ & $\%$ \\
\hline 1. & Title $(0-1)$ & 135 & 100 & 102 & 100 & 33 & 100 \\
\hline 2. & Address $(0-2)$ & 113 & 83.7 & 87 & 85.3 & 26 & 78.8 \\
\hline 3. & Name of assuror $(0-1)$ & 135 & 100 & 102 & 100 & 33 & 100 \\
\hline 4. & Location of assuror $(0-1)$ & 131 & 97.0 & 100 & 98.0 & 31 & 93.9 \\
\hline 5. & Report date $(0-1)$ & 135 & 100 & 102 & 100 & 33 & 100 \\
\hline 6. & Responsibilities of reporter $(0-1)$ & 133 & 98.5 & 102 & 100 & 31 & 93.9 \\
\hline 7. & Responsibilities of assuror $(0-1)$ & 131 & 97.0 & 101 & 99.0 & 30 & 90.9 \\
\hline 8. & Independence of assuror from reporting org. $(0-1)$ & 108 & 80.0 & 80 & 78.4 & 28 & 84.9 \\
\hline \multirow[t]{3}{*}{9.} & Impartiality of assuror towards stakeholders $(0-1)$ & 37 & 27.4 & 12 & 11.7 & 25 & 75.8 \\
\hline & & \multicolumn{2}{|c|}{ Mean $=87.1$} & \multicolumn{2}{|c|}{ Mean $=85.8$} & \multicolumn{2}{|c|}{ Mean $=90.9$} \\
\hline & B. Assurance procedures & & & & & & \\
\hline 10. & Scope of the assurance engagement $(0-1)$ & 133 & 98.5 & 100 & 98.0 & 33 & 100 \\
\hline 11. & Objective of the assurance engagement $(0-2)$ & 135 & 100 & 102 & 100 & 33 & 100 \\
\hline 12. & Competencies of assuror $(0-2)$ & 90 & 66.7 & 63 & 61.8 & 27 & 81.8 \\
\hline 13. & Criteria used to asses evidence and reach conclusion $(0-2)$ & 133 & 98.5 & 101 & 99.0 & 32 & 97.0 \\
\hline 14. & Assurance standard used $(0-2)$ & 131 & 97.0 & 102 & 100 & 29 & 87.9 \\
\hline \multirow[t]{3}{*}{15.} & Summary of work performed $(0-1)$ & 133 & 98.5 & 100 & 98.0 & 33 & 100 \\
\hline & & \multicolumn{2}{|c|}{ Mean $=93.2$} & \multicolumn{2}{|c|}{ Mean $=92.8$} & \multicolumn{2}{|c|}{ Mean $=94.5$} \\
\hline & C. Recommendations and opinion & & & & & & \\
\hline 16. & Materiality (from a stakeholder perspective) $(0-3)$ & 56 & 41.5 & 34 & 33.3 & 22 & 66.7 \\
\hline 17. & Completeness $(0-1)$ & 66 & 48.9 & 44 & 43.1 & 22 & 66.7 \\
\hline 18. & Responsiveness to stakeholders $(0-1)$ & 41 & 30.4 & 22 & 21.6 & 19 & 57.6 \\
\hline \multirow[t]{2}{*}{19.} & General conclusion / opinion $(0-2)$ & 134 & 99.3 & 101 & 99.0 & 33 & 100 \\
\hline & & \multicolumn{2}{|c|}{ Mean $=55.0$} & \multicolumn{2}{|c|}{ Mean $=49.3$} & \multicolumn{2}{|c|}{ Mean $=72.8$} \\
\hline
\end{tabular}

Table 4 presents the descriptive statistics for quality of assurance. The minimum score of assurance quality is 11 , with the maximum score is 26 . The mean quality score is 18.97 , and the median value is 18.00 , with standard deviation of 3.47. As the possible score of quality is ranged from 0 to 27 , the descriptive statistic shows that the quality of assurance provided is reasonably high. The value of mean and median is nearly equal, thus, the value of each sample is around its mean value.

Table 4. Descriptive statistics for quality of assurance by assurance provider

\begin{tabular}{l|c|c|c|c|c|c|c|}
\hline \multirow{2}{*}{ Assurance provider } & \multirow{2}{*}{$\mathbf{N}$} & \multicolumn{4}{|c}{ Quality of assurance statement } \\
\cline { 2 - 6 } & & Min & Max & Mean & Median & SD \\
\hline Accounting firms & 102 & 13 & 25 & 18.09 & 17.00 & 2,736 \\
\hline Non-accounting firms & 33 & 11 & 26 & 21.70 & 22.00 & 4,073 \\
\hline Total sample & 135 & 11 & 26 & 18.97 & 18.00 & 3.47 \\
\hline
\end{tabular}

The number of assurance statement provided by accounting firms are 102 assurance statements with the minimum quality score are 13 , and the maximum score is 25 . The mean quality score is 18.09 , and the median value is 17.00 with standard deviation of 2.736. It shows that the assurance statements provided by accounting firms have fairly high quality. On the other hand, the number of assurance statement provided by non-accounting firms are 33 assurance statements with the minimum quality score 11 , and the maximum score is 26 . The mean quality score is 21.70 , and the median value is 22.00 with standard deviation of 4.073 . This finding indicates that non-accounting firms provided higher quality of assurance statements compared to accounting firms. 
The result of the t-test between the quality of assurance statement provided by accounting firms, and non-accounting firms can be seen on Table 5. The mean quality value of assurance statements provided by accounting firm is 18.09 while the one provided by specialists or consultants is 21.70 . F score for Levene's test is 11.202 which significant at 0.05 level ( $p$-value $=0.001)$. This means that the variance is unequal. Therefore, the value of $t$ used is the one on "equal variances not assumed" which is -4.754 with significance of 0.000 . The $\mathrm{t}$ value is significant (sig. $<0.05$ ), thus, the quality of assurance statement provided by accounting firms and non-accounting firms differ significantly. Therefore, the hypothesis is supported. This finding is consistent with. They find that the quality of assurance is influenced by the type of provider.

Table 5. Independent sample t-test

\begin{tabular}{l|c|c|c|c|}
\hline $\begin{array}{l}\text { Mean of accounting firms }=18.09 \\
\text { Mean of non-accounting firms }=21.70\end{array}$ & \multicolumn{3}{c}{} \\
& Levene's Test for Equality of Variances & \multicolumn{2}{c}{ t-test for Equality of Means } \\
\hline & F & Sig. & t & Sig. (2-tailed) \\
\hline Equal variances assumed & 11.202 & 0.001 & -5.792 & 0.000 \\
\hline Equal variances not assumed & & & -4.754 & 0.000 \\
\hline
\end{tabular}

In terms of mean quality score, taking assurance statements provided by accounting firms, for instance, report the mean quality score is 13.71 , while the current study shows the mean quality score is 18.09 . This trend indicates a significant increasing of assurance quality score from 13.71 to be 18.09 . The improvement of assurance statement quality might be driven by the adoption of assurance standard. Perego and Kolk (2012) explain that many assurance statements do not comply to any standard. They find that there are 31 assurance statements (68.90 per cent) in 2005 and 40 assurance statements ( 48.80 per cent) in 2008 that do not refer to any present standards. Currently, there are 3 standards available in regard with assurance: AA1000AS provided by AccountAbility, ISAE3000 provided by IFAC, and GRI. Edgley, Jones \& Atkins (2015) propose that the accounting assurors legally obliged to employ ISAE3000 while non-accounting assurors using AccountAbility and GRI guidelines. Regardless of which standard is used, it seems that more assurance providers invest in and adopt the standard to conduct the assurance services nowadays as the demand of the assurance service keep increasing. As the index is used for measuring the quality was developed by employing the component of the standards, the adoption of standards will result in the higherquality scores of assurance statements.

Another possible reason is that the existence of corporate governance initiatives related to the practice of assurance. For example, Australia introduced the National Greenhouse and Energy Reporting Act 2007 (NGERS) and the Clean-Energy legislation in 2011 to ensure the credibility of information from reporting the Green-house Gas (Martinov-Bennie, 2012). In South Africa, the King III Code obliged the company's sustainability reports should be assured independently (Marx \& van Dyk, 2011). As a result, the significant increase in the number of independent assurance report in South Africa is due to the company's desire to comply with the King III Code (Ackers \& Eccles, 2015).

The interesting finding of this study shows that non-accounting firms provide higher quality of assurance statement than accounting firms (see Table 5). Given that about three-quarters of the samples choose accounting firm as the assurance provider, the overall quality of assurance provided is somewhat lower than the one provided by nonaccounting firms. One of the possible explanations is that specialists or consultants take the more evaluative approach than accountants (O'Dwyer \& Owen, 2005). Moreover, they argue that accounting firms seems to rely on their brand name whom they take a less extensive approach. Specialists or consultants are more elaborate and informative in formulating recommendation and giving positive assurance (Perego \& Kolk, 2012). Further, accounting firms seems to take a more cautious and conservative approach that they are hesitant to give clear conclusions due to the uncertainties surrounding the domain of sustainability assurance provision. On the other hand, non-accounting firms focus more on broader CSR performance and reporting frameworks, so that they make more comprehensive and balanced conclusions. 


\section{CONCLUSION}

This study investigated the quality of the assurance statement. In particular, it examined the nature of report content such as the report format, assurance procedures and assuror recommendations. One hundred thirty-five Fortune Global 500 companies in 2014 were selected as the samples. They are selected because these companies are multinational companies, which have been actively released the CSR report. In addition, they have been frequently used in previous studies. Considering that the multinational companies consist of many stakeholders, the transparency and credibility to sustainability reports are an obligation that must be encountered by firm.

Assurance provider has a relevant effect on the quality of assurance statement. The evidence from descriptive analysis shows that in terms of the contents of the report, both in the format of the report, assurance procedures, as well as recommendations, the non-accounting firm assurors provide higher quality than the accounting firm. Even though empirical evidence previously stated the accounting firm assurors dominated the assurance market, and they also provide more credible assurance statements, there is a recent evidence that indicates the non-accounting firm assurors do better assure the quality assurance statement. This finding will give a positive development in the thirdparty assurance service.

The result of this study suggetss that accounting firms take less extensive approach compared to non-accounting firm assurance providers. In addition, accounting firms seems to take the more cautious and conservative approach that they are hesitant to give clear conclusions due to the uncertainties surrounding the domain of sustainability assurance provision. An important implication of this finding is that the company not only to consider the reputation of the assurance provider, but the more important thing is competence and expertise in the field of sustainability reporting. This study determines assurance quality by merely doing content analysis on assurance statements provided. Future study should investigate the reasons to choose assurance providers, especially accounting firms since the profession seem to dominate the sustainability report assurance market and to define the quality of assurance in more comprehensive ways also to investigate how investors value the assurance statements provided by the companies.

\section{AUTHOR BIOGRAPHIES}

Tarmizi Achmad is an Associate Professor of Accounting at Department of Accounting Diponegoro University, Semarang-Indonesia. He is currently as a Vice Director of Ph.D. Programme at Faculty of Economics and Business Diponegoro University, Semarang Indonesia. He is a member of Indonesia Chartered Accountant. His research interest is in financial reporting and corporate governance areas. He published articles in International Journal of Managerial and Financial Accounting, The Journal of Global Business Issues.

Faisal Faisa is an Associate Professor of Accounting at Department of Accounting Diponegoro University, Semarang-Indonesia. His main research is in sustainability reporting area. He published some articles in International Journal of Managerial and Financial Accounting, Australasian Accounting Business and Finance Journal, Journal of Human Resource Costing and Accounting, and The Indonesian Journal of Accounting Research.

Muhammad Bahrul Ulum is graduated student from Accounting Department, Diponegoro University.

\section{REFERENCES}

Ackers, B. \& Eccles, N. S. (2015). Mandatory corporate social responsibility assurance practices: The case of King III in South Africa. Accounting, Auditing \& Accountability Journal, 28 (4):515-550.

Ballou, B., Heitger, D. L. \& Landes, C. E. (2006). The future of corporate sustainability reporting: A rapidly growing assurance opportunity. Journal of Accountancy, 202 (6):65-74.

Branco, M. C., Delgado, C., Gomes, S. F. \& Eugénio, T. C. P. (2014). Factors influencing the assurance of sustainability reports in the context of the economic crisis in Portugal. Managerial Auditing Journal, 29 (3):237-252.

Brown-Liburd, H. \& Zamora, V. L. (2015). The role of corporate social responsibility (csr) assurance in investors' judgments when managerial pay is explicitly tied to csr performance. AUDITING: A Journal of Practice \& Theory, 34 (1):75-96.

Cho, C. H., Michelon, G., Patten, D. M. \& Roberts, R. W. (2014). CSR report assurance in the USA: an empirical investigation of determinants and effects. Sustainability Accounting, Management and Policy Journal, 5 (2):130-148. 
Cohen, J. R. \& Simnett, R. (2015). CSR and assurance services: A research agenda. AUDITING: A Journal of Practice \& Theory, 34 (1):59-74.

CorporateRegister. (2013). CR Perspective 2013: Global CR reporting trend and stakeholders view. In CorporateRegister (Ed.).

De Beelde, I. \& Tuybens, S. (2015). Enhancing the credibility of reporting on corporate social responsibility in Europe. Business Strategy and the Environment, 24 (3):190-216.

Deegan, C., Cooper, B. J. \& Shelly, M. (2006). An investigation of TBL report assurance statements: UK and European evidence. Managerial Auditing Journal, 21 (4):329-371.

Edgley, C., Jones, M. J. \& Atkins, J. (2015). The adoption of the materiality concept in social and environmental reporting assurance: A field study approach. The British Accounting Review, 47 (1):1-18.

Faisal, F., Greg, T. \& Rusmin, R. (2012). Legitimising corporate sustainability reporting throughout the world. Australasian Accounting, Business and Finance Journal, 6 (2):19-34.

Francis, J. R. \& Yu, M. D. (2009). Big 4 office size and audit quality. The Accounting Review, 84 (5):1521-1552.

Gomes, S. F., Eugénio, T. C. P. \& Branco, M. C. (2015). Sustainability reporting and assurance in Portugal. Corporate Governance: The international journal of business in society, 15 (3):281-292.

Green, W. \& Taylor, S. (2013). Factors that influence perceptions of greenhouse gas assurance provider quality. International Journal of Auditing, 17 (3):288-307.

GRI, G. R. I. (2013). The external assurance of sustainability reporting. In G. R. Initiative (Ed.), Research \& Development Series. Amsterdam.

Herda, D. N., Taylor, M. E. \& Glyn, W. (2014). The effect of country-level investor protection on the voluntary assurance of sustainability reports. Journal of International Financial Management \& Accounting, 25 (2):209-236.

Hodge, K., Subramaniam, N. \& Stewart, J. (2009) Assurance of sustainability reports: Impact on report users' confidence and perceptions of information credibility. Australian Accounting Review, 19 (3):178-194.

Jones, M. J. \& Solomon, J. F. (2010). Social and environmental report assurance: Some interview evidence. Accounting Forum, 34 (1):20-31.

Junior, R. M., Best, P. J. \& Cotter, J. (2014). Sustainability reporting and assurance: A historical analysis on a world-wide phenomenon. Journal of Business Ethics, 120 (1):1-11.

Kend, M. (2015). Governance, firm-level characteristics and their impact on the client's voluntary sustainability disclosures and assurance decisions. Sustainability Accounting, Management and Policy Journal, 6 (1):54-78.

Knechel, W. R., Wallage, P., Eilifsen, A. \& Praag, B. v. (2006). The demand attributes of assurance services providers and the role of independent accountants. International Journal of Auditing, 10 (2):143-162.

Kolk, A. \& Perego, P. (2010). Determinants of the adoption of sustainability assurance statements: An International investigation. Business Strategy and the Environment, 19 (3):182-198.

KPMG. (2013). The KPMG survey of corporate responsibility reporting 2013. In K. International (Ed.), KPMG International Cooperative.

Martinov-Bennie, N. (2012). Greenhouse gas emissions reporting and assurance: reflections on the current state. Sustainability Accounting, Management and Policy Journal, 3 (2):244-251.

Marx, B. \& van Dyk, V. (2011). Sustainability reporting and assurance: An analysis of assurance practices in South Africa. Meditari Accountancy Research, 19 (1/2):39-55.

Milne, M. J. \& Adler, R. W. (1999). Exploring the reliability of social and environmental disclosures content analysis. Accounting, Auditing \& Accountability Journal, 12 (2):237-256.

Mock, T. J., Rao, S. S. \& Srivastava, R. P. (2013). The development of worldwide sustainability reporting assurance. Australian Accounting Review, 23 (4):280-294.

Mock, T. J., Strohm, C. \& Swartz, K. M. (2007). An examination of worldwide assured sustainability reporting. Australian Accounting Review, 17 (41):67-77.

Moroney, R., Windsor, C. \& Aw, Y. T. (2012). Evidence of assurance enhancing the quality of voluntary environmental disclosures: an empirical analysis. Accounting \& Finance, 52 (3):903-939.

O'Dwyer, B. \& Owen, D. L. (2005). Assurance statement practice in environmental, social and sustainability reporting: a critical evaluation. The British Accounting Review, 37 (2):205-229.

O'Dwyer, B. (2011). The case of sustainability assurance: Constructing a new assurance service. Contemporary Accounting Research, 28 (4):1230-1266.

O’Dwyer, B., Owen, D. \& Unerman, J. (2011). Seeking legitimacy for new assurance forms: The case of assurance on sustainability reporting. Accounting, Organizations and Society, 36 (1):31-52.

Park, J. \& Brorson, T. (2005). Experiences of and views on third-party assurance of corporate environmental and sustainability reports. Journal of Cleaner Production, 13 (10-11):1095-1106.

Perego, P. (2009). Causes and consequences of choosing different assurance providers: An international study of sustainability reporting. International Journal of Management, 26 (3):412-425.

Perego, P. \& Kolk, A. (2012). Multinationals' accountability on sustainability: The evolution of third-party assurance of sustainability reports. Journal of Business Ethics, 110 (2):173-190. 
Pflugrath, G., Roebuck, P. \& Simnett, R. (2011). Impact of assurance and assurer's professional affiliation on financial analysts' assessment of credibility of corporate social responsibility information. AUDITING: A Journal of Practice \& Theory, 30 (3):239-254

Simnett, R., Vanstraelen, A. \& Chua, W. F. (2009). Assurance on sustainability reports: An international comparison. The Accounting Review, 84 (3):937-967.

Watts, R. L. \& Zimmerman, J. L. (1983). Agency problem, auditing, and the theory of the firm: Some evidence. Journal of Law and Economics, 26 (3):613-633.

Wong, R. \& Millington, A. (2014). Corporate social disclosures: a user perspective on assurance. Accounting, Auditing \& Accountability Journal, 27 (5):863-887.

Zorio, A., García-Benau, M. A. \& Sierra, L. (2013). Sustainability development and the quality of assurance reports: Empirical evidence'. Business Strategy and the Environment, 22 (7):484-500. 


\section{Appendix A}

\begin{tabular}{|c|c|c|c|c|}
\hline No & $\begin{array}{l}\text { Ranking } \\
\text { Criteria }\end{array}$ & Definition & Score & Explanation \\
\hline \multirow{2}{*}{1} & \multirow{2}{*}{ Title } & \multirow{2}{*}{ Title of the assurance statement } & 0 & No reference \\
\hline & & & 1 & Reference \\
\hline \multirow{3}{*}{2} & \multirow{3}{*}{ Addressee } & \multirow{3}{*}{$\begin{array}{l}\text { Party to whom the assurance statement is } \\
\text { formally addressed (eitherin title separate } \\
\text { addressee line or within text) }\end{array}$} & 0 & No reference \\
\hline & & & 1 & Addressee is internal or "the readers" \\
\hline & & & 2 & $\begin{array}{l}\text { Stakeholder mentioned in the } \\
\text { addressee }\end{array}$ \\
\hline \multirow{2}{*}{3} & \multirow{2}{*}{ Name of assuror } & \multirow{2}{*}{$\begin{array}{l}\text { Name of the firm that conducts the } \\
\text { assurance engagement }\end{array}$} & 0 & No reference \\
\hline & & & 1 & Reference \\
\hline \multirow{2}{*}{4} & \multirow{2}{*}{$\begin{array}{l}\text { Location of } \\
\text { assuror }\end{array}$} & \multirow{2}{*}{$\begin{array}{l}\text { Location of the office of the assurance } \\
\text { provider }\end{array}$} & 0 & No reference \\
\hline & & & 1 & Reference \\
\hline \multirow{2}{*}{5} & \multirow{2}{*}{ Report date } & \multirow{2}{*}{$\begin{array}{l}\text { Reference to the date at which the assurance } \\
\text { exercise was finished }\end{array}$} & 0 & No reference \\
\hline & & & 1 & Reference \\
\hline \multirow[b]{2}{*}{6} & \multirow{2}{*}{$\begin{array}{l}\text { Responsibilities } \\
\text { of reporter }\end{array}$} & \multirow{2}{*}{$\begin{array}{l}\text { Explicit statement that reporter is } \\
\text { responsible for preparation of report } \\
\text { (keywords: responsible, responsibility) }\end{array}$} & 0 & No reference \\
\hline & & & 1 & Reference \\
\hline \multirow[b]{2}{*}{7} & \multirow{2}{*}{$\begin{array}{l}\text { Responsibilities } \\
\text { of assuror }\end{array}$} & \multirow{2}{*}{$\begin{array}{l}\text { Explicit statement that the reporter is } \\
\text { responsible to express an (independent) } \\
\text { opinion on the subject matter }\end{array}$} & 0 & No reference \\
\hline & & & 1 & Reference \\
\hline \multirow[b]{2}{*}{8} & \multirow[b]{2}{*}{$\begin{array}{l}\text { Independence of } \\
\text { assuror from } \\
\text { reporting } \\
\text { organization }\end{array}$} & \multirow[b]{2}{*}{$\begin{array}{l}\text { Statement expressing the independence of } \\
\text { the two parties involved (a } 1 \text { is assigned as } \\
\text { soon as the word(s) independent or } \\
\text { independence appear anywhere in the } \\
\text { assurance statement or its title. Thus, } \\
\text { remarks such as "this is an independent } \\
\text { opinion...' 'already qualifies for a 1) }\end{array}$} & 0 & No reference \\
\hline & & & 1 & $\begin{array}{l}\text { Reference or mere statement } \\
\text { expressing that independence can be } \\
\text { looked up on the internet }\end{array}$ \\
\hline 9 & $\begin{array}{l}\text { Impartiality of } \\
\text { assuror towards } \\
\text { stakeholders }\end{array}$ & $\begin{array}{l}\text { Assuror's declaration of impartiality with } \\
\text { respect to } \\
\text { stakeholder interests }\end{array}$ & $\begin{array}{l}0 \\
1\end{array}$ & $\begin{array}{l}\text { No reference } \\
\text { Reference (a remark that such a } \\
\text { declaration can be made available on } \\
\text { request or reference to an internet site } \\
\text { already qualifies a 1) }\end{array}$ \\
\hline \multirow[b]{2}{*}{10} & \multirow{2}{*}{$\begin{array}{l}\text { Scope of the } \\
\text { assurance } \\
\text { engagement }\end{array}$} & \multirow{2}{*}{$\begin{array}{l}\text { Assurance statement coverage (a } 1 \text { is } \\
\text { assigned if anywhere in the assurance } \\
\text { statement the coverage of the assurance } \\
\text { exercise is stated) }\end{array}$} & 0 & No reference \\
\hline & & & 1 & Reference \\
\hline \multirow{3}{*}{11} & \multirow{3}{*}{$\begin{array}{l}\text { Objective of the } \\
\text { assurance } \\
\text { engagement }\end{array}$} & \multirow{3}{*}{$\begin{array}{l}\text { Objective to be achieved through the } \\
\text { engagement (indicating the level of } \\
\text { assurance intended) }\end{array}$} & 0 & No reference \\
\hline & & & 1 & $\begin{array}{l}\text { Review, limited assurance, } \\
\text { independent opinion, independent } \\
\text { assurance, external verification, } \\
\text { external assurance or validation }\end{array}$ \\
\hline & & & 2 & $\begin{array}{l}\text { Reasonable assurance or reasonable } \\
\text { and limited assurance (e.g., two } \\
\text { different levels of assurance for } \\
\text { different parts of the report) }\end{array}$ \\
\hline \multirow{3}{*}{12} & \multirow{3}{*}{$\begin{array}{l}\text { Competencies of } \\
\text { assuror }\end{array}$} & \multirow{3}{*}{$\begin{array}{l}\text { Description of the professional skills that } \\
\text { enable the engagement team to conduct the } \\
\text { assurance exercise }\end{array}$} & 0 & No reference \\
\hline & & & 1 & $\begin{array}{l}\text { Statement claiming competency (but } \\
\text { no explanatory note) or mere reference } \\
\text { to an internet site }\end{array}$ \\
\hline & & & 2 & $\begin{array}{l}\text { Explanatory statement of } \\
\text { competencies based on prior } \\
\text { experience/engagements }\end{array}$ \\
\hline
\end{tabular}

(Appendix continued on next page) 


\begin{tabular}{|c|c|c|c|c|}
\hline \multirow[b]{3}{*}{13} & \multirow{3}{*}{$\begin{array}{l}\text { Criteria used to } \\
\text { asses evidence } \\
\text { and reach } \\
\text { conclusion }\end{array}$} & \multirow{3}{*}{$\begin{array}{l}\text { A statement that makes reference to } \\
\text { particular criteria against which the } \\
\text { sustainability report has been prepared (e.g. } \\
\text { GRI and often internally developed } \\
\text { standards) }\end{array}$} & 0 & No reference \\
\hline & & & 1 & $\begin{array}{l}\text { Reference to publicly unavailable } \\
\text { criteria }\end{array}$ \\
\hline & & & 2 & $\begin{array}{l}\text { Reference to publicly available criteria } \\
\text { (e.g., internally developed criteria that } \\
\text { are published anywhere in the report } \\
\text { or GRI) }\end{array}$ \\
\hline \multirow{3}{*}{14} & \multirow{3}{*}{$\begin{array}{l}\text { Assurance } \\
\text { standard used }\end{array}$} & \multirow{3}{*}{$\begin{array}{l}\text { Standards used which govern the work of } \\
\text { the assurance provider (e.g. AA1000AS or } \\
\text { ISAE3000) }\end{array}$} & 0 & No reference \\
\hline & & & 1 & $\begin{array}{l}\text { Reference to publicly unavailable } \\
\text { criteria }\end{array}$ \\
\hline & & & 2 & Reference to publicly available criteria \\
\hline \multirow{2}{*}{15} & \multirow{2}{*}{$\begin{array}{l}\text { Summary of work } \\
\text { performed }\end{array}$} & \multirow{2}{*}{$\begin{array}{l}\text { Statement explaining the actions taken to } \\
\text { arrive at a conclusion }\end{array}$} & 0 & No reference \\
\hline & & & 1 & Reference \\
\hline \multirow{4}{*}{16} & \multirow{4}{*}{$\begin{array}{l}\text { Materiality (from } \\
\text { a stakeholder } \\
\text { perspective) }\end{array}$} & \multirow{4}{*}{$\begin{array}{l}\text { Degree of information provision on } \\
\text { materiality level. If the conclusion states } \\
\text { that the report is in conformance with the } \\
\text { AA } 1000 \text { principles (materiality, complete- } \\
\text { ness, and responsiveness) this qualifies for a } \\
\text { reference and thus a } 1 \text { is assigned }\end{array}$} & 0 & No reference \\
\hline & & & 1 & $\begin{array}{l}\text { Reference limited to a broad statement } \\
\text { assuror has not undertaken any work } \\
\text { to confirm that all relevant/material } \\
\text { issues are included }\end{array}$ \\
\hline & & & 2 & $\begin{array}{l}\text { Reference and explanation of } \\
\text { materiality setting or reference limited } \\
\text { to a broad statement and stakeholder } \\
\text { perspective introduced (e.g. "issues } \\
\text { material to stakeholders have been } \\
\text { considered") }\end{array}$ \\
\hline & & & 3 & $\begin{array}{l}\text { Reference, explanation of materiality } \\
\text { setting and stakeholder perspective } \\
\text { introduced }\end{array}$ \\
\hline \multirow[b]{2}{*}{17} & \multirow[b]{2}{*}{ Completeness } & \multirow{2}{*}{$\begin{array}{l}\text { Statement expressing that all material } \\
\text { aspects are covered by the report. If the } \\
\text { conclusion states that the report is in } \\
\text { conformance with the AA } 1000 \text { principles } \\
\text { (materiality, completeness, and } \\
\text { responsiveness) this qualifies for a reference } \\
\text { and thus a } 1 \text { is assigned }\end{array}$} & 0 & No reference \\
\hline & & & 1 & Reference \\
\hline \multirow[b]{2}{*}{18} & \multirow[b]{2}{*}{$\begin{array}{l}\text { Responsiveness } \\
\text { to stakeholders }\end{array}$} & \multirow{2}{*}{$\begin{array}{l}\text { Statement referring to the organization's } \\
\text { procedures (or lack of them) for identifying } \\
\text { stakeholder interests and concerns. If the } \\
\text { conclusion states that the report is in } \\
\text { conformance with the AA } 1000 \text { principles } \\
\text { (materiality, completeness. And } \\
\text { responsiveness) this qualifies for a reference } \\
\text { and thus a } 1 \text { is assigned }\end{array}$} & 0 & No reference \\
\hline & & & 1 & Reference \\
\hline \multirow{3}{*}{19} & \multirow{3}{*}{$\begin{array}{l}\text { General } \\
\text { conclusion / } \\
\text { opinion }\end{array}$} & \multirow{3}{*}{$\begin{array}{l}\text { Statement expressing the result of the } \\
\text { assurance exercise. If there is no general } \\
\text { conclusion but the conclusion solely refers } \\
\text { to the } 3 \text { principles of AA } 1000 \text { (materiality, } \\
\text { completeness, and responsiveness) a } 0 \text { is } \\
\text { assigned) }\end{array}$} & 0 & No reference \\
\hline & & & 1 & $\begin{array}{l}\text { Mere statement expressing the opinion } \\
\text { of the assuror (e.g., 'XY's report is a } \\
\text { fair presentation of XY's CSR } \\
\text { performance''). A } 1 \text { is assigned only if } \\
\text { the conclusion consists only of one } \\
\text { sentence }\end{array}$ \\
\hline & & & 2 & $\begin{array}{l}\text { Explanatory statement (more than one } \\
\text { sentence, but recommendations for } \\
\text { improvement are not considered part } \\
\text { of the conclusion) }\end{array}$ \\
\hline
\end{tabular}

